\title{
Anoplura (lice) infestation of the herb wood mouse Sylvaemus uralensis Pallas, 1811 in the Trans-Urals forest-steppe
}

\author{
$V P$ Starikov ${ }^{*}$, and $V N$ Kravchenko \\ Surgut State University 628412, Surgut, Lenina av., 1, tel.: (3462)-76-31-59
}

\begin{abstract}
The herb wood mouse is parasitized by Hoplopleura affinis Burmeister, 1839. For this research, the authors examined a total number of 408 herb wood mice for the presence of permanent ectoparasites (lice). The authors considered changes in the infestation rate in connection with the periods of the rodent's life, the age and gender composition of the lice, the biotopic confinement peculiarities of the parasite in the conditions of the Trans-Urals forest steppe (Kurgan region). H. affinis is noted to be found on mammals in contact with the herb wood mouse.
\end{abstract}

\section{Introduction}

P.N. Krylov was the first to introduce the term forest-steppe as a botanical-geographical zonal division [1]. Before this, the term "predsteppe" was used [2]. The Trans-Urals foreststeppe is customarily understood as a part of the steppe zone of Western Siberia, which is limited by the Trans-Ural peneplain in the west, and by the valley of the Ishim river in the east [3-4]. The territory is a part of the Ob-Irtysh formation of the Trans-Volga-Kazakhstani fratria. It is characterized by the rich poaceae-forb meadow-steppes and steppe meadows, in combination with birch steppe forests, and the predominance of halophytic varieties of meadow -steppes and steppe meadows in a complex with poor herb or even halophyticsteppe groups of solonetz and salt marshes [5].

Small mammals are of a particular interest among the animals of the Trans-Urals (Kurgan oblast) as their role in biocenoses and human economic activity is quite significant.

The herb wood mouse Sylvaemus uralensis Pallas is nocturnal. Near water bodies, it lives together with the Eurasian water vole Arvicola amphibius Linnaeus, 1758, the root vole Alexandromys oeconomus Pallas, 1776, the harvest mouse Micromys minutus Pallas, 1771, and other species of small mammals. Lately, in the study of the genus Sylvaemus there has been the prevalence of taxonomic researches involving the use of karyological, allozyme, and molecular genetic methods [6-7]. Parasitological studies are rare [8-9]. The herb wood mouse Sylvaemus uralensis Pallas is one of the main pests of forestry and agriculture in the forest-steppe subzone of the Southern Trans-Urals. Lice, fleas, ixodidae and gamasid ticks parasitize mice, which makes them dangerous in a sanitary sense [10-11].

* Corresponding author: vp_starikov@mail.ru 
The beginning of the systematic development and compilation of lice guides parasitizing wild mammals belongs to G.F. Ferris [12-17]. Following him, some catalogs of this group of parasitic arthropods in small mammals appeared for certain territories: S. Wegner [18] for Poland, J.K. Becourne [19] for France, D.I. Blagoveshchensky [20] for the European part of Russia, V.N. Zarubina [21] for the South-Eastern Transbaikal, and V.N. Zarubina [22] for the Far East of the USSR.

In Russia, lice got into the scope of parasitologists' attention only after the researches of the natural infectious diseases carried out by E.N. Pavlovsky. In the abstract of her dissertation, V.N. Zarubina [21] reports that one family and seven genera represent the fauna of the former USSR territory; there are about 61 species. Representatives of the genus Hoplopleura are among the most widespread Anoplura. Hoplopleura acanthopus is the most studied and widespread. The ecology and biology of Hoplopleura affinis, a specific louse of the genera Salvaemus and Apodemus, are less studied or practically not studied [23]. Perhaps this is because only in 1951 G.F. Ferris described this species of louse as an independent one based on the collections of the Palaearctic and Neotropical regions. This specimen was previously considered and defined as one of the morphological variations of Poliplax serrata. The epidemiological role of this species is still not fully studied. Among the scientific researches, one can find only a single study of $H$. affinis for infestation with pathogens. J. Lachmeier and S. Wegner [24] reported on isolating the encephalitis virus from the population. This disease can also be found on the territory of the Trans-Urals forest-steppe [25].

\section{Materials and methods}

The field study of the small mammals was being carried out from the beginning of May to the end of August 2020 on the territory of the Trans-Urals forest-steppe (Kurgan oblast in the Ketovsky and Pritobolny districts). To be examined for the presence of lice, the animals were captured by using the methods of trapping grooves and trap lines [26-27]. A total of 2 035 small mammals were captured (Salvaemus uralensis made up more than $20 \%$ of the specimens). Russian and Latin names of small mammal species are given according to A.A. Lisovsky et al. [28].

Anoplura were collected from wild small mammals in accordance with the method of D.I. Blagoveshchensky [21]. The captured animals were examined from head to tail. Anoplura were found in the scalp near the skin. The collected parasitic arthropods were fixed in $70 \%$ alcohol. To collect lice eggs, the hair was pulled out or cut with scissors. Parasites were identified and studied using whole-mount, fixation with Fora-Berlise solution [29].The qualifiers of D.I. Blagoveshchensky [20], J.C. Beaucurnu and V.N. Zarubina [22] were used to determine the species. Latin names of species are given according to L. Durden and G. G. Musser [23].

When studying the ecology of the $H$. affinis population, much attention was paid to the quantitative study, determination of the numerical ratio of genders, age composition, etc. Following the norms adopted in faunistic studies, we divided the hosts of parasites into main, additional, and accidental [8]. In the quantitative study of the population, we used the terms and concepts recommended by V.N. Beklemishev [30]. The average number of parasite individuals per host individual - the abundance index (AI); the percentage of host individuals on which a given type of parasite was found in relation to the total number of examined host individuals - occurrence index (OI) were taken into account.

The statistical significance of the occurrence index values was examined according to the formula proposed by K.P. Fedorov [31]: 


$$
t_{d i f}=\frac{P_{1}-P_{2}}{\sqrt{M_{p 1}^{2}+M_{p 2}^{2}}} ; M_{P}=\sqrt{\frac{P(100-P)}{n}}
$$

$\mathrm{P}_{1}$ and $\mathrm{P}_{2}$ - comparable occurrence indices, \%;

$\mathrm{M}_{\mathrm{P} 1}, \mathrm{M}_{\mathrm{P} 2}$ - their errors; $\mathrm{n}$ - the number of the examined animals.

The reliability criterion of differences in the abundance index was determined according to the formula proposed by P.V. Terentyev and N.S. Rostova [32]:

$$
t=\frac{\bar{X}_{1}-\bar{X}_{2}}{F} ; F=\sqrt{\frac{S_{1}^{2}(n-1)+S_{2}^{2}(n-1)}{n_{1}+n_{2}-2}} \sqrt{\frac{n_{1}+n_{2}}{n_{1} n_{2}}}
$$

$\mathrm{X}_{1}, \mathrm{X}_{2}$ - comparable abundance indices;

$S_{1}^{2}, S_{2}^{2}-$ their standard deviations;

$\mathrm{n}_{1}, \mathrm{n}_{2}-$ sizes of compared samples.

\section{Results and discussion}

According to the research of L.M. Syuzumova [33], the density of mice number in individual biotopes undergoes changes during the year. This is due to both regular seasonal movements of animals and impact of some abiotic factors, such as drought, spring floods, non-periodic fluctuations in the level of groundwater, and other climatic conditions characteristic of the Trans-Urals forest steppe. Perhaps that is why the specimens of the herb wood mouse that we researched were mainly found in biotopes located near water bodies.

Quite similar types of biotopes, in which the infestation of the animals was uniform, are combined into the groups. The herb wood mouse in the Trans-Urals forest steppe is moderately infested with $H$. affinis, the highest infestation indices inherent to the rodents caught in the groups of such biotopes as near-water (riverside and lakeside) biotopes and fields of perennial grasses (Table 1).

The distribution of Anoplura in the host population is uneven: some specimens do not have them, others have only few, in most specimens the intensity of infestation is close to average, but in some individuals there are hundreds, and sometimes thousands of lice. It seems that due to such highly invasive individuals, parasites persist and spread in host populations. In the Pritobolny district of the Kurgan oblast, the maximal infestation with $S$. uralensis was noted in the neighborhood of Zaborskoye village and the former "Yolochka" base of the Kurgan State University: 65 and 68 lice specimens, respectively. These values are not limiting. E.F. Sosnina [34] noted the maximal infestation of more than 200 individuals of the parasite in the forest belt of the mountainous Crimea.

Table 1. Hoplopleura affinis infestation of the herb wood mouse in different groups of biotopes

\begin{tabular}{|c|c|c|c|c|c|}
\hline \multirow[b]{2}{*}{ Biotopes group } & \multicolumn{2}{|c|}{$\begin{array}{c}\text { Number of the } \\
\text { examined mammals }\end{array}$} & \multicolumn{3}{|c|}{ Infestation indices ${ }^{1}$} \\
\hline & examined & infested & 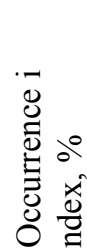 & 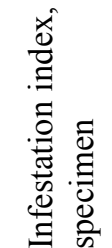 & 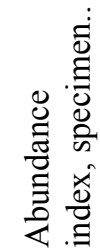 \\
\hline near-water (riverside and lakeside) & 316 & 25 & 7.91 & 15.16 & 1.20 \\
\hline birch and aspen-birch small forests & 14 & 1 & 7.14 & 8.00 & 0.57 \\
\hline
\end{tabular}
of the Trans-Urals forest-steppe 
ecotones (small forests - fields of winter crops, small forests pedestrian meadows, meadow steppe $\begin{array}{lllll}17 & 1 & 5.88 & 1.00 & 0.06\end{array}$ - fields of winter crops)

\begin{tabular}{lcccccc}
\hline fields of perennial grasses & 12 & 1 & 8.33 & 10.00 & 0.83 \\
\hline settlements, buildings & & 40 & - & - & - & - \\
\hline $\begin{array}{l}\text { Pritobolsk pine forests, } \\
\text { plantations }\end{array}$ & pine & 9 & - & - & - & - \\
\hline $\begin{array}{l}\text { meadow steppe } \\
\text { All biotopes }\end{array}$ & - & - & - & - & - \\
\hline
\end{tabular}

The general breeding period of the herb wood mouse in the Trans-Urals forest-steppe lasts approximately from April to September [11]. Pregnant females can be met until the end of September and bring 2-3 litters over the summer. There can be up to eight offspring in one litter. Animals in the first litter are already capable of breeding in the same season and begin to lead an active lifestyle with a weight of about $7.5 \mathrm{~g}$ and a body length of about $60 \mathrm{~mm}[11]$.

Comparing the Anoplura infestation in the age groups of the herb wood mouse, regardless of gender (Table 2), we can see that the infestation rates of young animals that have just started their independent life are already quite high, but still below the average for population. The percentage of infestation in semi-adult individuals is almost 2 times higher, the infestation index is 1.5 and the abundance index is 3.1 times higher than in mice that have just left their burrows.

When all age groups are united, almost all indicators are statistically insignificant in males and are higher $\left(\mathrm{t}_{\mathrm{emp}}=1.54\right.$, at $\mathrm{p}=0.05$, $\left.\mathrm{t}_{\text {theor }}=1.97\right)$ than in females, only the infestation index is higher in females. Perhaps it is related to the fact that females contact more with other individuals of their species, primarily with their offspring, thereby they reduce their infestation rate and increase the number of hosts, thus increasing the frequency of occurrence. This tendency was observed by E.F. Sosnina [35].

Table 2. Hoplopleura affinis infestation in the herb wood mouse of different ages and gender in the Trans-Urals forest-steppe

\begin{tabular}{|c|c|c|c|c|c|c|c|c|c|}
\hline \multirow[b]{2}{*}{ Age group* } & \multicolumn{3}{|c|}{$\begin{array}{c}++\hat{O} \hat{O} \\
\text { Infestation indices }\end{array}$} & \multicolumn{3}{|c|}{$\begin{array}{c}+9 \\
\text { Infestation indices }\end{array}$} & \multicolumn{3}{|c|}{$\begin{array}{c}\hat{O} \hat{O} \\
\text { Infestation indices }\end{array}$} \\
\hline & 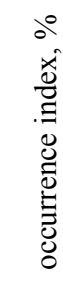 & 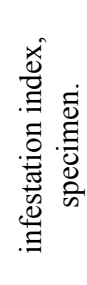 & 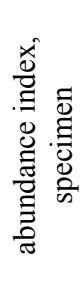 & 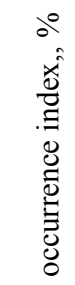 & 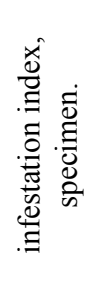 & 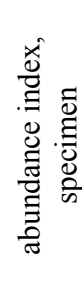 & 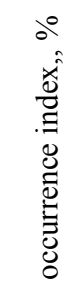 & 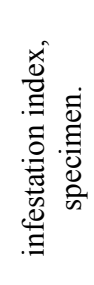 & 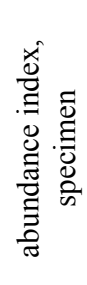 \\
\hline young & 3.45 & 10.00 & 0.34 & 6.67 & 10.00 & 0.67 & - & - & - \\
\hline semi-adult & 6,83 & 15.43 & 1.05 & 6.09 & 14.67 & 0.77 & 8.89 & 16.01 & 1.42 \\
\hline adult & 7.47 & 13.92 & 0.29 & 4.11 & 17.00 & 0.70 & 9.90 & 13.00 & 1.29 \\
\hline $\begin{array}{l}\text { All over the } \\
\text { gather }\end{array}$ & 6.62 & 14.78 & 0.37 & 4.93 & 14.90 & 0.73 & 8.29 & 14.71 & 1.22 \\
\hline
\end{tabular}

Note: * age groups of the herb wood mouse are distinguished according to Pavlinin V.N., Schwartz S.S [11].

Seasonal fluctuations inherent to the maximum extent to the temporary ectoparasites, which activity outside the host's body depends on temperature, humidity, and other 
environmental factors. Despite the fact that lice are permanent ectoparasites of small mammals, seasonal dynamics were also noted for them.

In spring, at the beginning of May, the rodent breeding season begins and continues till the end of September. The infection rates of the herb wood mouse were gradually increasing during the entire study period, the peak of the infection intensity (OI 1.53) was in July. E.F. Sosnina [35] also noted fluctuations in the number of Anoplura, which was associated with the breeding periods of the parasites' hosts.

During the entire study period in the demographic structure of $H$. affinis, females predominated in the population $(63.4 \%)$; the proportion of males and larvae in the population of this species is significantly lower (Table 3), only in July the predominance of larvae of different stages of development over males was observed (Table 3). Lice eggs on animals with average infection rates were located either on the abdomen, back, withers or head; eggs of the parasite were observed throughout the host's body in mice with indicators above average.

Table 3. Age and gender composition of the Hoplopleura affinis in the herb wood mouse in the Trans-Urals forest-steppe

\begin{tabular}{lc|c|c|c}
\hline \multirow{2}{*}{ Month } & \begin{tabular}{c} 
Number of \\
mammals \\
\cline { 3 - 5 }
\end{tabular} & \multicolumn{3}{c}{ Percentage of lice } \\
\hline May & 76 & 75.0 & 16.7 & 8.3 \\
June & 77 & 85.0 & 5.0 & 10.0 \\
July & 143 & 58.4 & 15.1 & 26.5 \\
August & 112 & 66.7 & 21.2 & 12.1 \\
All over the gather & 408 & 63.4 & 17.0 & 19.6 \\
\hline
\end{tabular}

The presence of Anoplura in unusual species of animals is of a special interest, as it may indicate close intraspecific contacts. Isolated presence of $H$. affinis in the wood mouse Sicista betulina Pallas, 1779, the tundra shrew Sorex tundrensis Merriam, 1900, the common shrew S. araneus Linnaeus, 1758, and the Eurasian pygmy shrew Sorex minutus Linnaeus, 1766, is possibly related to the specific activity of this group. For example, shrews lack permanent burrows, so they often visit the burrows and nests of rodents and eat their corpses.

\section{Conclusion}

On the territory of the Trans-Urals forest-steppe, H. affinis was registered for the first time. Parasitizing the herb wood mouse by $H$. affinis along with other species of lice was not detected, $6.86 \%$ of $S$. uralensis was infected. The main host of $H$. affinis is $S$. uralensis; accidental hosts are Sorex araneus, S. tundrensis, S. minutus, and Sicista betulina. The highest rates of infestation inherent to the animals of the near-water biotopes, where the most favourable conditions for the habitation of the herb wood mouse in the Trans-Urals forest-steppe are formed. Anoplura abundance peaks correspond to the periods of the highest breeding intensity of hosts. In the age and gender structure of $H$. affinis, females predominated in the population during the entire study period; the proportion of males and larvae in the population of this species is significantly lower

\section{References}

1. A. G. Voronov, Porfiry Nikitich Krylov, Russian physics-geographers and travelers (Moscow, 1959) 
2. A. N. Beketov, Geography of plants: an outline of the study of the vegetation distribution on the earth's surface: with a special addition about European Russia. (Typ. V. Demakova, Saint-Petersburg, 1896)

3. N. M. Stupina, Geomorphology of the Trans-Ural forest steppe // Natural conditions and forests of the Trans-Urals forest steppe Sverdlovsk 19 pp 5-21 (1960)

4. Geography of the Kurgan oblast: study guide (Kurgan, 2019)

5. I. S. Ilyina, Ye. I. Lapshina, V. D. Makhno and Ye. A. Romanova, Geobotanical zoning. Inset on the map "Vegetation of the West Siberian Plain" (Moscow, 1976)

6. A. S. Bogdanov, D. M. Atopkin, G. N. Chelomina, Bulletin of the Russian Academy of Sciences, 3, 276- (2000)

7. V.V. Stakheev, A. S. Bogdanov, D. I. Vodolazhsky, Genetika, 47(5) 660-670 (2011)

8. Yu. S. Balashov, Parasitology, 38(6), 481-491 (2004)

9. Yu. S. Balashov, A. V. Bochkov, V. S. Vashchenok and others, Parasitology, 41(5), 329-47 (2007)

10. A. V. Novikova, Collection of abstracts, information materials of the Institute of Plant and Animal Ecology, 8-10 (Ural department, Science Academy of USSR, Sverdlovsk, 1974)

11. V. N. Pavlinin, S. S. Schwartz, Mouse-like (Myomorphs) rodents of the Urals (Sverdlovsk Book Publishing House, Sverdlovsk, 1953)

12. G. F. Ferris, A catalogue and host list of the Anoplura vol. 6, 129- 213 (1916)

13. G. F. Ferris, Contributions toward a monograph of the sucking lice, vol. 2, 52-133 (1921)

14. G. F. Ferris, Contributions toward a monograph of the sucking lice, vol. 2, 134-78 (1922)

15. G. F. Ferris, Contributions toward a monograph of the sucking lice, vol. 2, 134- 78 (1923)

16. G. F. Ferris, Contributions toward a monograph of the sucking lice, vol. 2, 271- 413 (1932)

17. G. F. Ferris, Contributions toward a monograph of the sucking lice, vol. 2, 527- 634 (1935)

18. Z. Wegner, Katalog fauny Polski (Państwowe wydawnictwo naukowe, Warszawa, 1966)

19. J. C. Beaucournu, Annales de parasitologie (Paris), 43 201-71 (1968)

20. D. I. Blagoveshchenskiy, Field guide of the insects of the European part of the USSR 1, 324-334 (Nauka, Moscow; Leningrad, 1964) vol. pp.

21. V. N. Zarubina, Methodological recommendations for collecting and determining lice of wild mammals of the South-Eastern Transbaikalia (Irkutsk regional printing house No. 1, Irkutsk, 1970)

22. V. N. Zarubina, Field guide of the insects of the Far East of the USSR ed. by P A Lera vol. 1, 370-377 (Nauka, Leningrad, 1986)

23. L. A. Durden and G. G. Musser, The sucking lice (Insecta, Anoplura) of the world: a taxonomic checklist with records of mammalian hosts and geographical distributions (Number, New York, 1994)

24. J. Lachmajer and Z. Wegner, Biul. Inst. Med. Morsk., 10, 175-184 (1959)

25. State report "on the state of sanitary and epidemiological welfare of the population in 
the Kurgan region in 2014" (Kurgan, 2015)

26. N. P. Naumov, Questions of regional, general and experimental parasitology and medical zoology, 9, 179-202 (1955)

27. V. V. Kucheruk, Organization and methods of accounting for birds and harmful rodents, 159-84 (Publishing house of the USSR Academy of Sciences, Moscow, 1963)

28. A. A. Lissovsky, B. I. Sheftel, A. P. Saveljev, O. A. Ermakov, Yu. A. Kozlov, D. G. Smirnov, V. V. Stakheev, D. M. Glazov, Mammals of Rossia: species list and applied issues vol 56 (KMK Scientific Press, Moscow, 2019)

29. I. G. Ioff Field guide of the fleas of Eastern Siberia, the Far East and adjacent regions (Medgiz, Moscow, 1954)

30. V. N. Beklemishev, Zool. J., 40 149-58 (1961)

31. K. P. Fedorov Regularities of the spatial distribution of parasitic worms (Science, Novosibirsk, 1986)

32. P. V. Terentyev and N. S. Rostova Workshop on biometrics (Publishing house of Leningrad University, Leningrad, 1977)

33. L. M. Syuzumova, Natural conditions and forests of the Trans-Urals forest steppe (Sverdlovsk), 19, 145-54 (1960)

34. E. F. Sosnina, Parasitology, 4(4), 371-4 (1970)

35. E. F. Sosnina, I. V. Nazarova and L. Kh. Sadekova, Parasitology, 15(2), 157-62 (1981) 